2. Порядок формування тематики наукових досліджень і науковотехнічних (експериментальних) розробок, що фінансуються за рахунок коштів державного бюджету: затв. постановою Кабінету Міністрів України від 11 січня 2018 р. № 13. URL: https://zakon.rada.gov.ua/ laws/show/13-2018-п\#Tехt (дата звернення: 06.03.2021).

3. Про страховий фонд документації України: Закон України від 23 березня 2001 р. № 2332-III / Верховна Рада України. URL: https://zakon.rada.gov.ua/laws/show/2332-14\#Tех (дата звернення: 06.03.2021).

4. Державний реєстр технологій. URL: http://rkt.ukrintei.ua/search

DOI https://doi.org/10.30525/978-9934-26-046-9-58

\title{
ОГЛЯД СУЧАСНОЇ ТЕХНІКИ ДЛЯ МЕХАНІЗАЦЇ̈ ТЕХНОЛОГІЧНИХ ПРОЦЕСІВ У САДІВНИЦТВІ
}

\author{
Кутковецька Т. О. \\ кандидат економічних наук, доиент, \\ дочент кафедри агроінженерії \\ Уманський національний університет садівництва \\ Дідур В. В. \\ кандидат технічних наук, \\ дочент кафедри агроінженерії \\ Уманський національний університет садівництва \\ м. Умань, Черкаська область, Україна
}

На сьогодні використання сучасної сільськогосподарської техніки в будь-якій галузі є невід'ємною складовою ведення господарства, що в свою чергу дає можливість як найменших витрат на виробництво 3 отриманням високого прибутку в майбутньому. Галузь садівництва $\epsilon$ трудомісткою галуззю, тому без використання засобів механізації технологічних процесів у садівництві неможливе ведення його на сучасному рівні.

Як при вирощуванні сільськогосподарських культур, так і при веденні садівництва виконуються наступні роботи: обробіток грунту, догляд за насадженнями та збір урожаю. Для наведеного виду 
робіт використовується сучасна техніка вітчизняного та зарубіжного виробництва.

Серед сучасного виробництва сільськогосподарської техніки для обробітку грунту відзначається культиватор типу CFX [1], що використовується для міжрядного обробітку грунту в садах (Рис. 1).

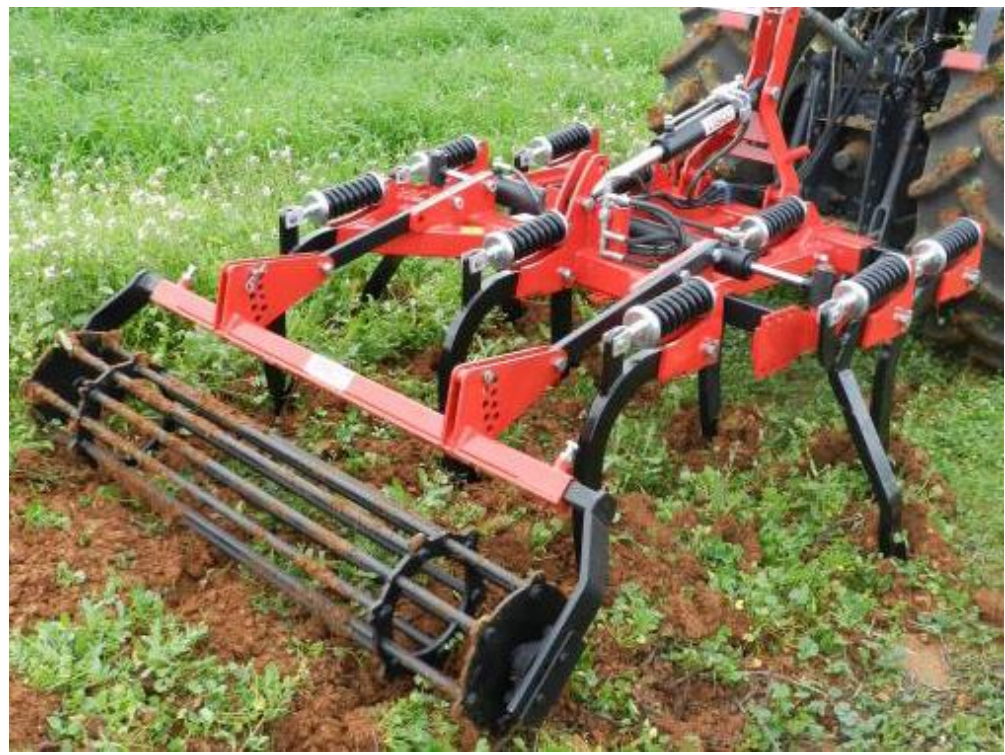

\section{Рисунок 1. Культиватор типу CFX для міжрядного обробітку грунту в садах}

Культиватор типу CFX спеціально розроблений для міжрядного обробітку грунту у виноградниках і фруктових садах. До основних переваг культиватора належать: конструктивно передбачене підтримання однакової відстані між стійками, незалежно від того, чи знаходиться культиватор повністю в розсунутому, чи звуженому стані, що дозволяє уникати забивання рослинними рештками та працювати на глибині до 25 см; подвійний гідравлічний циліндр з синхронізованим розширенням; підготовлене до монтажу обладнання для міжстовбурного обробітку грунту; С-подібні стійки з пружинами; міцна рама i роботизоване зварювання; легка і швидка навіска на будь-який трактор; місце встановлення передніх металевих коліс. 
Ще однією новинкою, що використовується для догляду за насадженнями $\epsilon$ обладнання для обробітку міжстовбурної зони дерев у садах типу ID WEEDER (Рис. 2) [3].

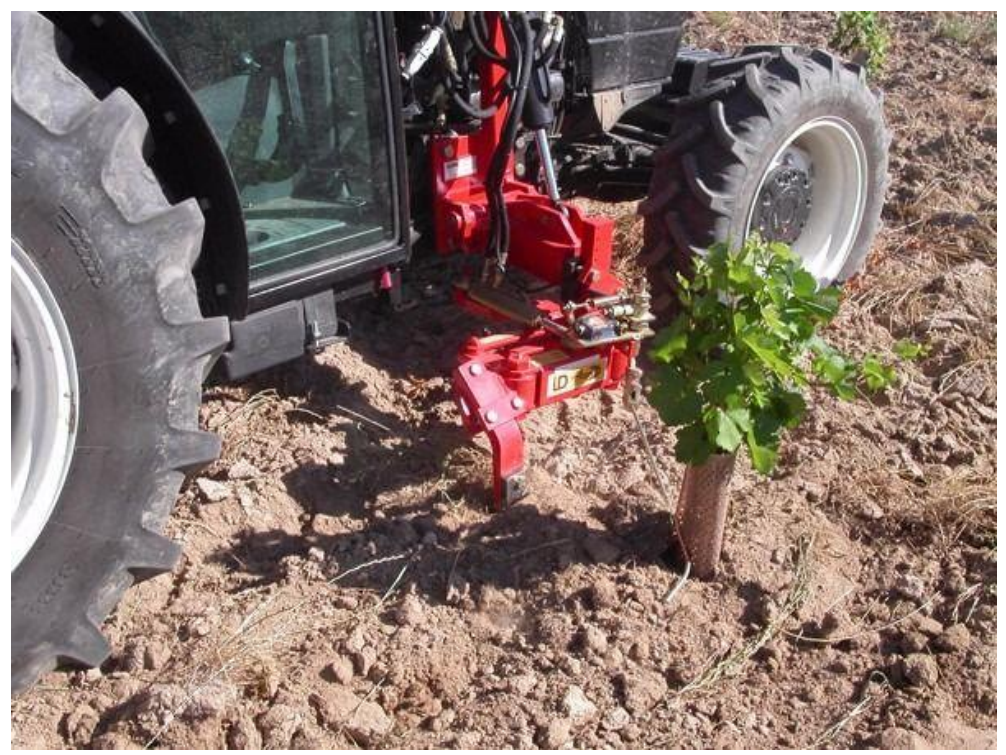

\section{Рисунок 2. Обладнання для обробітку міжстовбурної зони дерев у садах типу ID WEEDER}

Дане обладнання встановлюється на будь-яку раму або культиватор і використовується для боротьби з бур'янами. Прополка здійснюється між насадженнями, що висаджені рядами (це виноградники та фруктові сади). Основними перевагами є: електрогідравлічний важіль, що призначений для роботи навколо рослин навіть 3 дуже малою товщиною з різними змінними робочими органами, які дозволяють обробляти поверхню, як без заглиблення, так і з глибиною обробітку до 20 см, під контролем регульованого датчика 3 індуктивним сенсором; ексклюзивна система, що поєднує в собі паралелограмне зміщення робочого знаряддя разом з радіальним рухом, забезпечує високу точність і велику стійкість навіть при відхиленнях, що перевищують 30 см при вирівнюванні рослин або при рухові трактора по рядах плантації; дозволяє працювати зі швидкістю до 12 км/год. 
Одним із трудомістких процесів у садівництві є збирання врожаю. Основні причини, які гальмують створення засобів для механізованого збирання врожаю, полягають в особливостях фізико-механічних властивостей плодів та плодових дерев, великій різноманітності схем садіння дерев та типів крони. Крім того, більшість плодів дуже чутливі до механічних дій, що значно ускладнює механізацію цього процесу. Проте сучасне виробництво сільськогосподарської техніки все ж таки вирішило дану проблему та представило ряд сучасної техніки для збирання плодів з різними удосконаленими механізмами. До лідерів виробників техніки для механізації технологічних процесів у садівництві можна віднести країни Німеччини, Італії, Польщі, США та ін. [4]

Як зазначалося вище, на сьогодні існує велика кількість сучасних машин для збирання врожаю й одними із розповсюджених технічних засобів для збирання плодів $є$ машини, робочий орган яких трусить стовбур, а плоди падають на розтягнуте під кроною полотно. Наприклад, такою $є$ машина польського виробництва фірми WEREMCZUK MAJA AUTOMATIC (Рис. 3) [2].

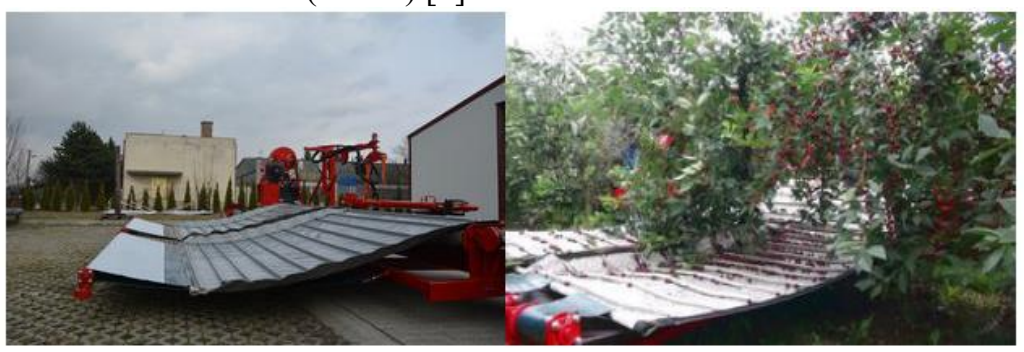

\section{Рисунок 3. Машина для струшування та очищення вишень та слив}

Наведена модель машини може працювати з будь-якою відстанню між деревами. Гарантує високу ефективність збирання врожаю (майже 100 \%) та високу якість зібраних плодів. Може використовуватися для збирання фундука, мигдалю та промислових яблук.

Таким чином, нами розглянуто лише деякі машини, що використовуються в садівництві. Проте, в сучасному виробництві сільськогосподарської техніки представлена дуже велика кількість машин для механізації технологічних процесів в садівництві з різними конструктивними рішеннями. Машини, які виробляються, постійно модерні- 
зуються та удосконалюються, в залежності від посадки саду, типів крони, виду плодів та інше. Сучасні машини можуть забезпечити потреби будь-якого господарства, починаючи від малих фермерських садів до садів промислового рівня.

\section{Література:}

1. Культиватор для міжрядної обробки саду типу СFX. URL: https://agsolco.com/ua/kultivator_dlya_mezhduryadnoy_obrabotki_ sada_tipa_cfx/ (дата звернення: 16.02.2021).

2. Новий ягодозбиральний комбайн WEREMCZUK MAJA AUTOMATIC URL: https://autoline.ua/-/prodazh/yagodozbiralni-kombayni/WEREMCZUK-MAJA-AUTOMATIC17032211530486689500 (дата звернення: 08.03.2021).

3. Обладнання для обробки міжстовбурової зони дерев в саду ID WEEDER, що монтується на культиватор. URL: https:/agsolco.com/ua/ oborudovanie_dlya_obrabotki_mezhstvolovoy_zony_derevev_v_sadu_id_ weeder_montiruemoe_na_kultivator/ (дата звернення: 16.02.2021).

4. Погорілий В., Мігальов А. Механізація збирання фруктів один із шляхів підвищення ефективності садівництва. Науково-виробничий журнал «Техніка і технологї̈ АПК». 2017. № 9 (96). С. 7-14. 